\title{
GREEN CHEMISTRY-BASED EXPERIMENTS AS THE IMPLEMENTATION OF SUSTAINABLE DEVELOPMENT VALUES
}

\author{
Maria Paristiowati ${ }^{{ }^{*}}$, Zulmanelis $^{\mathbf{1}}$ and Muhamad Fazar Nurhadi ${ }^{\mathbf{1}}$ \\ ${ }^{1}$ Department of Chemistry Education, Universitas Negeri Jakarta, Jakarta 13220, Indonesia \\ *E-mail: maria.paristiowati@unj.ac.id
}

\begin{abstract}
ABSTRAK
Pengembangan eksperimen kimia berbasis green chemistry bertujuan untuk melatih dan membiasakan mahasiswa agar menghemat penggunaan bahan-bahan kimia, menggantinya dengan bahan-bahan yang lebih aman dan meminimalisasi limbah yang dihasilkan dari kegiatan praktikum. Metode penelitian dan pengembangan digunakan untuk mengembangkan modul praktikum berbasis green chemistry. Tahapan penelitian dan pengembangan terdiri dari: analisis kebutuhan, pengembangan produk, dan uji coba produk. Modul praktikum yang dikembangkan, mengimplementasikan tiga prinsip green chemistry, yaitu mencegah limbah, perencanaan bahan kimia yang lebih aman dan penggunaan pelarut yang aman. Hasil uji kelayakan oleh ahli materi dan ahli media menghasilkan skor berturut-turut sebesar $91,9 \%$ dan $94,7 \%$. Hasil uji coba pada kelompok kecil dan kelompok besar menunjukkan bahwa modul praktikum berbasis green chemistry ini layak digunakan. Persepsi mahasiswa setelah menggunakan modul, menunjukkan hasil yang positif. Kesimpulan dari hasil uji kelayakan dan uji coba yang dilakukan menunjukkan bahwa modul kinetika kimia berbasis green chemistry memiliki kriteria baik dan sesuai dengan keinginan serta kebutuhan mahasiswa. Selain itu implementasi modul ini dalam praktikum kinetika kimia berhasil membuat mahasiswa memahami serta mengaplikasikan prinsip green chemistry. Sebanyak $90 \%$ mahasiswa menyadari bahwa ada hubungan antara penerapan prinsip green chemistry dengan paradigma pendidikan untuk pembangunan berkelanjutan. Penggunaan modul kinetika kimia berbasis green chemistry juga menghemat biaya kebutuhan bahan praktikum sebesar $75 \%$ setiap tahunnya.
\end{abstract}

Kata kunci: praktikum kimia, green chemistry, pembangunan berkelanjutan

\begin{abstract}
The development of a chemistry experiment based on green chemistry aims to train and familiarize students to save on the use of chemicals, replace them with safer materials and minimize waste generated from experimental activities. Research and development methods are used to develop experimental modules based on green chemistry. The stages of research and development consist of needs analysis, product development, and product testing. The developed experiment module, implements three principles of green chemistry, i.e. preventing waste, safer chemical planning and safe use of solvents. The feasibility test by expert judgement on the material and media obtained scores $91.9 \%$ and $94.7 \%$ respectively. The results of the trials in small groups and large groups showed that the developed module was feasible to use. Student perceptions after using the module show positive results. The conclusions from the results of the feasibility test and the trial conducted indicate that the green chemistry-based kinetics' module has good criteria and in accordance with the wishes and needs of students. In addition, the implementation of this module in the kinetics experiment succeeded in making students understand and apply the principles of green chemistry. As many as $90 \%$ of students realize that there is a relationship
\end{abstract}


between the application of the principles of green chemistry and the educational paradigm for sustainable development. The use of kinetics' module based on green chemistry also saved the cost of experiment material requirements by $75 \%$ per year.

Keywords: chemistry experiment, green chemistry, sustainable development

DOI: http://dx.doi.org/10.15575/jtk.v4i1.3566

\section{INTRODUCTION}

Sustainable development declared by the United Nations since 2005 is a comprehensive paradigm in all aspects of life (Wals, 2012). The concept of sustainable development is described as development that meets current needs, but does not reduce the ability of the next generation to meet their own needs. Education has a central role to instill the values of sustainable development early on. The field of chemistry education has contributed in instilling the values of sustainable development during experiments in the laboratory. Chemistry experiments can be applied through a basic model of the approach to sustainability issues, i.e. adopting the principles of green chemistry for practicing science education, and adding sustainability strategies as content in chemistry education. In addition, the use of controversial issues related to sustainable development for socioscientific problems can encourage chemistry education as part of the development of Education for Sustainable Development (ESD) based schools (Burmeister et al., 2012).

The principle of green chemistry is important to adopt to conduct laboratory experiments, because the use of chemicals in experiments and research in chemical laboratories has the potential to produce waste. Waste generated from chemical laboratories can contribute to environmental pollution if overused or use hazardous chemicals. Green chemistry combines a new approach to the synthesis, processing and application of chemical substances in such a manner as to reduce threats to health and the environment (Anastas et al., 2001; Singh et al., 1999; Wardencki et al., 2005). The advantages of applying green chemistry to the lab work are lower experiment cost, energy saving, and reducing waste. The benefits are to protect human health and the environment, and to create a healthier work environment.

The idea of green chemistry is to concern in managing chemicals using, producing and evaluating their impact on the environment. The application of green chemistry has already begun in several activities such as field trips for school activities (Aubrecht et al., 2015), integration of green chemistry in the chemistry curriculum (Karpudewan et al., 2015). In addition, the idea of green chemistry has also begun to be applied in some educational materials such as books and modules.

Recent study showed several green chemistrybased experiment modules have been developed, such as experiment module in Basic Chemistry (Wahyuningsih, 2017), Rate of Reaction (Fitrian and Fadiawati, 2014), and Solutions (Wardana and Sultoni, 2017). The modules in this study integrate the principles of green chemistry in chemical experiments. In the module, there is an experimental procedure, also equipped with material about green chemistry and a comparison table of 

Values

materials before and after applying green chemistry. Students are trained and accustomed to save the use of chemicals, replacing them with safer materials and minimizing waste from experimental activities. So, in the experimental activities based on green chemistry, students will instill the values of sustainable development.

\section{Green Chemistry}

The term of green chemistry was first used in 1991 by Anastas in a special program launched by the Environmental Protection Agency (EPA) to carry out sustainable development in the field of chemistry and industry. Green chemistry combines new approaches for the synthesis, processing and application of chemicals in such a way to reduce threats for health and environment. The idea of green chemistry is essentially concern to managing chemicals, producing and evaluating their impact on the environment. Green chemistry is a comprehensive approach that applied o all aspects of chemistry by designing chemical products and processes to reduce or eliminate the use of hazardous materials (Anastas et al., 2001).

Green chemistry focuses its views on the problem of finding more environmentally friendly chemical process methods, reducing, and preventing pollution and pollution sources. The application of green chemistry is needed because in the chemical production stage, the energy consumed is very large, inefficient, involves toxic substances, and produces hazardous waste. Therefore, green chemistry experts work to ensure that the chemical products produced only have minimal harmful effects on human health and the environment. One way is to prioritize the use of alternative and renewable materials including using agricultural or biomass waste (Beaulne, 2009). The advantage of applying green chemistry to the lab is more economical, it can save energy, reduce the waste produced so as to protect human health and the environment and create a healthier work environment (Beaulne, 2009). Green chemistry has 12 principles that have been declared, as listed in the table 1 below.

Table 1. The Principles of Green Chemistry (Anastas, 1998)

\begin{tabular}{|c|c|c|}
\hline No. & Principle & Annotation \\
\hline 1 & Prevention & $\begin{array}{l}\text { It is better to prevent } \\
\text { waste than to treat or } \\
\text { clean up waste after it } \\
\text { has been created. }\end{array}$ \\
\hline 2 & $\begin{array}{l}\text { Atom } \\
\text { economy }\end{array}$ & $\begin{array}{l}\text { Synthetic methods } \\
\text { should be designed to } \\
\text { maximize the } \\
\text { incorporation of all } \\
\text { materials used in the } \\
\text { process into the final } \\
\text { product. }\end{array}$ \\
\hline 3 & $\begin{array}{l}\text { Less } \\
\text { hazardous } \\
\text { chemical } \\
\text { syntheses }\end{array}$ & $\begin{array}{l}\text { Wherever practicable, } \\
\text { synthetic methods } \\
\text { should be designed to } \\
\text { use and generate } \\
\text { substances that } \\
\text { possess little or no } \\
\text { toxicity to human } \\
\text { health and the } \\
\text { environment. }\end{array}$ \\
\hline 4 & $\begin{array}{l}\text { Designing } \\
\text { safer } \\
\text { chemicals }\end{array}$ & $\begin{array}{l}\text { Chemical products } \\
\text { should be designed to } \\
\text { affect their desired } \\
\text { function while } \\
\text { minimizing their } \\
\text { toxicity. }\end{array}$ \\
\hline 5 & $\begin{array}{l}\text { Safer solvents } \\
\text { and auxiliaries }\end{array}$ & $\begin{array}{l}\text { The use of auxiliary } \\
\text { substances (e.g., } \\
\text { solvents, separation } \\
\text { agents, etc.) should be } \\
\text { made unnecessary } \\
\text { wherever possible and } \\
\text { innocuous when used. }\end{array}$ \\
\hline 6 & $\begin{array}{l}\text { Design for } \\
\text { energy } \\
\text { efficiency }\end{array}$ & $\begin{array}{l}\text { Energy requirements } \\
\text { of chemical processes } \\
\text { should be recognized } \\
\text { for their } \\
\text { environmental and }\end{array}$ \\
\hline
\end{tabular}




\begin{tabular}{|c|c|c|}
\hline No. & Principle & Annotation \\
\hline & & $\begin{array}{l}\text { economic impacts and } \\
\text { should be minimized. } \\
\text { If possible, synthetic } \\
\text { methods should be } \\
\text { conducted at ambient } \\
\text { temperature and } \\
\text { pressure. }\end{array}$ \\
\hline 7 & $\begin{array}{l}\text { Use of } \\
\text { renewable } \\
\text { feedstocks }\end{array}$ & $\begin{array}{l}\text { A raw material or } \\
\text { feedstock should be } \\
\text { renewable rather than } \\
\text { depleting whenever } \\
\text { technically and } \\
\text { economically } \\
\text { practicable. }\end{array}$ \\
\hline 8 & $\begin{array}{l}\text { Reduce } \\
\text { derivatives }\end{array}$ & $\begin{array}{l}\text { Unnecessary } \\
\text { derivatization (use of } \\
\text { blocking groups, } \\
\text { protection/ } \\
\text { deprotection, } \\
\text { temporary } \\
\text { modification of } \\
\text { physical/chemical } \\
\text { processes) should be } \\
\text { minimized or avoided } \\
\text { if possible, because } \\
\text { such steps require } \\
\text { additional reagents } \\
\text { and can generate } \\
\text { waste. }\end{array}$ \\
\hline 9 & Catalysis & $\begin{array}{l}\text { Catalytic reagents (as } \\
\text { selective as possible) } \\
\text { are superior to } \\
\text { stoichiometric } \\
\text { reagents. }\end{array}$ \\
\hline 10 & $\begin{array}{l}\text { Design for } \\
\text { degradation }\end{array}$ & $\begin{array}{l}\text { Chemical products } \\
\text { should be designed so } \\
\text { that at the end of their } \\
\text { function they break } \\
\text { down into innocuous } \\
\text { degradation products } \\
\text { and do not persist in } \\
\text { the environment. }\end{array}$ \\
\hline 11 & $\begin{array}{l}\text { Real-time } \\
\text { analysis for } \\
\text { pollution } \\
\text { prevention }\end{array}$ & $\begin{array}{l}\text { Analytical } \\
\text { methodologies need } \\
\text { to be further } \\
\text { developed to allow for } \\
\text { real-time, in-process } \\
\text { monitoring and }\end{array}$ \\
\hline
\end{tabular}

\begin{tabular}{|l|l|l|}
\hline No. & Principle & \multicolumn{1}{c|}{ Annotation } \\
\hline & & $\begin{array}{l}\text { control prior to the } \\
\text { formation of } \\
\text { hazardous substances. }\end{array}$ \\
\hline 12 & $\begin{array}{l}\text { Substances and the } \\
\text { form of a substance } \\
\text { used in a chemical } \\
\text { process should be } \\
\text { chosen to minimize } \\
\text { the potential for } \\
\text { chemistry for } \\
\text { chemical accidents, } \\
\text { accident } \\
\text { including releases, } \\
\text { explosions, and fires. }\end{array}$ \\
\hline
\end{tabular}

\section{Education for Sustainable Development}

Sustainable development is development that meets current needs, but does not reduce its ability to meet the needs of the next generation. Sustainable development must pay attention to be environmental sustainability in utilizing the environment, so that the quality of the environment remains good (Wals, 2012). All sustainable development programs have been considered as three aspects of environmental, social and economic sustainability. Thus, the government and the community should identify priorities and create sustainable future goals.

Chemistry education has a central role in education for sustainable development (Burmeister et al., 2012). This is based on the core role of chemistry and the chemical industry in sustainable development, because many products in everyday life are based on chemistry. The chemical industry has great potential to focus on the environment both in terms of the production process and the final product. Therefore, chemical education must emphasize students' understanding of the role of chemistry in society and enhance their ability to evaluate business and products related to chemicals. For example, chemicals can affect the future, contribute to a sustainable society and assistance in the 

Values

proper management of natural resources (Burmeister et al., 2012).

Chemistry is also important in sustainability issues outside the professional world. Chemistry is used to understand many problems, such as climate change and effects for human, the production of alternative energy, etc. (Burmeister et al., 2012). Students will be the voice of citizens making decisions involving chemical applications. A key in ESD is the importance of recognizing the interrelationships between the ecological, social and economic dimensions of each problem.

Education for Sustainable Development, as defined by the UK Government, allows people to develop knowledge, values and skills to improve the quality of life now and without destroying the planet for the future through participation in decisions about how we do things individually and collectively both globally and locally (Summers et al., 2005). A key concept in this regard is the precautionary principle that emphasizes taking action to protect human health and the environment against possible future damage (Wals, 2012). The same idea from Burmeister emphasizes the main focus of ESD is to prepare young people to become responsible citizens in the future (Jegstad and Sinnes, 2015). Summers' definition about ESD and the broad idea of being responsible citizens are an important foundation in the definition of ESD (Summers et al., 2005).

\section{RESEARCH METHODOLOGY}

The research was using research and development method with these following steps of development which adopted from Gall et al. (2007). a. Needs analysis to determine the condition of the kinetic lab so that the experiment module is developed needed.

b. Plan the development of learning models and its equipment

c. Feasibility test.

d. Indicators assessed by the material expert consist of the substance of the material in the module with the curriculum, the accuracy of the material, the quality of the learning support materials, the quality of presentation, and the green chemistry aspect. While the indicators on the feasibility test by media experts consist of indicators of instructional quality and technical quality.

e. Trials on small and large groups.

f. Indicators in small and large group trials are quality relevance to learning objectives, content quality, language style, and technical quality.

g. Product implementation. At this stage, the questionnaires about the knowledge of green chemistry and questionnaires related to the student paradigm on education for sustainable development were distributed after the students conducted experiment.

\section{RESULTS AND DISCUSSION}

\subsection{Module Development}

The results of the use of chemicals survey on the kinetics experiment obtained the information on type and amount of chemicals used, included glacial acetic acid, benzene, chloroform, carbon tetrachloride, and ether. These five materials are used in considerable quantities and some are corrosive, toxic, and potentially carcinogenic. Therefore, by applying the principle of green chemistry in the implementation of the experiment, will anticipate the use of these materials. Implementation of green chemistry principles on kinetics practice is as follows: 

Implementation Of Sustainable Development Values

Table 2. The Implementation of Green Chemistry Principles

\begin{tabular}{|c|c|c|}
\hline No. & $\begin{array}{l}\text { Implementation of } \\
\text { Green Chemistry } \\
\text { Principles }\end{array}$ & Purpose \\
\hline 1 & $\begin{array}{l}\text { Reducing the volume } \\
\text { and concentration of } \\
\text { the materials. }\end{array}$ & $\begin{array}{l}\text { Preventing toxic } \\
\text { waste matter }\end{array}$ \\
\hline 2 & $\begin{array}{l}\text { a. Reduce the } \\
\text { volume of organic } \\
\text { solvents. } \\
\text { b. Replace with safer } \\
\text { chemicals } \\
\text { (chloroform and } \\
\text { acetone with } \\
\text { toluene and } \\
\text { ethanol) } \\
\end{array}$ & $\begin{array}{l}\text { a. Preventing } \\
\text { toxic waste } \\
\text { matter } \\
\text { b. Prevent } \\
\text { accidents }\end{array}$ \\
\hline 3 & $\begin{array}{l}\text { Reduce the mass of } \\
\text { phenol used }\end{array}$ & $\begin{array}{l}\text { Minimize the } \\
\text { amount of waste } \\
\text { generated }\end{array}$ \\
\hline 4 & $\begin{array}{l}\text { The use of } \mathrm{HCl} \text { is } \\
\text { replaced by the use } \\
\text { of acetic acid with a } \\
\text { smaller concentration } \\
\text { and volume of acetic } \\
\text { acid }\end{array}$ & $\begin{array}{l}\text { Produce the } \\
\text { least amount of } \\
\text { chemical waste } \\
\text { to human health } \\
\text { and the } \\
\text { environment }\end{array}$ \\
\hline 5 & $\begin{array}{l}\text { a. Reduce the } \\
\text { concentration of } \\
\text { acetic acid } \\
\text { b. Using butanol as } \\
\text { an organic } \\
\text { solvent for } \\
\text { replacing ether or } \\
\text { chloroform }\end{array}$ & $\begin{array}{l}\text { Preventing toxic } \\
\text { waste matter }\end{array}$ \\
\hline
\end{tabular}

Table 3. Use of Chemicals Before and After Applying Green Chemistry Principles

\begin{tabular}{|l|l|l|}
\hline Materials Used & $\begin{array}{l}\text { Before green } \\
\text { chemistry }\end{array}$ & $\begin{array}{l}\text { After } \\
\text { green } \\
\text { chemistry }\end{array}$ \\
\hline $\begin{array}{l}\text { Concentration of } \\
\mathrm{CH}_{3} \mathrm{COOC}_{2} \mathrm{H}_{5}\end{array}$ & $0,02 \mathrm{M}$ & $0,005 \mathrm{M}$ \\
\hline $\begin{array}{l}\mathrm{Concentration} / \\
\text { Volume of } \mathrm{NaOH}\end{array}$ & $\begin{array}{l}2,02 \mathrm{M} / \\
200 \mathrm{~mL}\end{array}$ & $\begin{array}{l}0,005 \mathrm{M} / \\
100 \mathrm{~mL}\end{array}$ \\
\hline $\begin{array}{l}\text { Concentration/ } \\
\text { Volume of } \mathrm{HCl}\end{array}$ & $\begin{array}{l}0,02 \mathrm{M} / \\
150 \mathrm{~mL}\end{array}$ & $\begin{array}{l}0,005 \mathrm{M} / \\
100 \mathrm{~mL}\end{array}$ \\
\hline $\begin{array}{l}\mathrm{Concentration} \text { of } \\
\mathrm{H}_{2} \mathrm{C}_{2} \mathrm{O}_{4}\end{array}$ & $0,01 \mathrm{M}$ & $0,0025 \mathrm{M}$ \\
\hline Solvent & $\begin{array}{l}\text { Benzene and } \\
\text { chloroform }\end{array}$ & $\begin{array}{l}\text { Ethyl } \\
\text { acetate }\end{array}$ \\
\hline
\end{tabular}

This experiment module is organized into several sections, including:

a. Introduction which contains information about the parts contained in the experiment module so that it can facilitate students in using the module.

b. Safety sheets in the laboratory which contain descriptions of personal protective equipment in the laboratory, material safety data sheets, waste disposal rules, and introduction of hazardous and toxic materials.

c. Text regarding green chemistry which contains explanations and principles of green chemistry.

d. Each experiment is equipped with a readiness test and final test, the principles of green chemistry that are applied, theoretical basis, work procedures and trial charts.

One of examples of the application of green chemistry in experiments is as follows: 


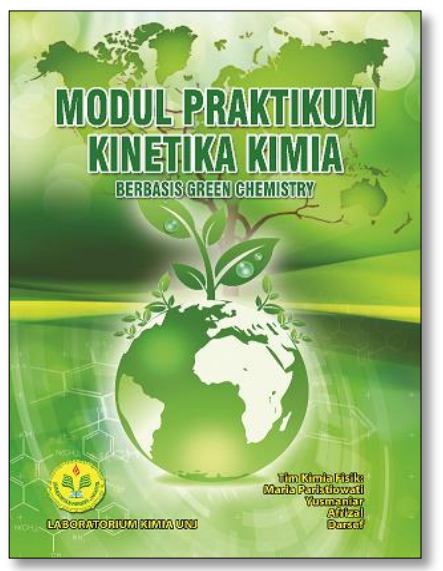

Figure 1. Cover of The Experiment Module

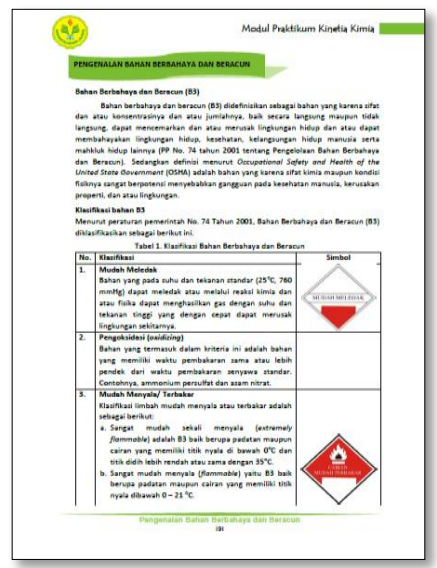

Figure 2. MSDS Page

\subsection{Result of Feasibility Test and Trial}

The results of the feasibility test by the expert obtained a score of $91.9 \%$ which showed very good interpretation. Results of module trials on small scale students are $70.5 \%$ and large scale is $72 \%$. The results of this trial show good interpretation. So it can be concluded that the sustainable chemistry-based experiment module in chemical kinetics already has good criteria. The benefit is making the students understand and apply the principles of green chemistry in life.

\subsection{Analysis Result}

At the end of the implementation phases, an assessment was done after doing chemistrybased chemicals kinetics lab. This assesment is to determine the extent to which the module
Green Chemistry-Based Experiments As The Implementation Of Sustainable Development Values

succeeds in providing knowledge related to green chemistry. To obtain the data, the researchers distributed questionnaires to students after doing the chemical kinetics experiment based on green chemistry.

In the first question, "Do you think that if chemicals use in Chemical Kinetics lab is excessive, can it have a negative impact on the environment?" $96 \%$ answered yes and $4 \%$ said no. These results indicate that students' awareness of excessive use of chemicals in the lab process can have an impact on the environment. It also means that students have started to apply green chemistry process laboratory experiment. In addition to the environment, students also show the awareness that waste can affect health. The results are derived from the second question, "Do you think the chemicals used in lab chemistry can produce health and environmental waste?" the result showed $89 \%$ said yes and $11 \%$ said no.

Student awareness that waste can adversely affect on the environment and health is also illustrated by the attitude of throwing away the waste produced in chemical kinetic labs at the proper place. Disposing waste in place can minimize waste pollution into the environment. The third question indicates that, "Do you always throw away the waste generated in a Chemical Kinetic lab in the proper place?" $80 \%$ answered yes and $20 \%$ said no. The fourth question is "is it necessary to apply the Green Chemistry principle in Chemical Kinetics practice?" 99\% of the results were answered yes and $1 \%$ said no.

Next, the fifth question is "What do you think about the follow-up to green chemistry?" The following results are obtained. 

Values

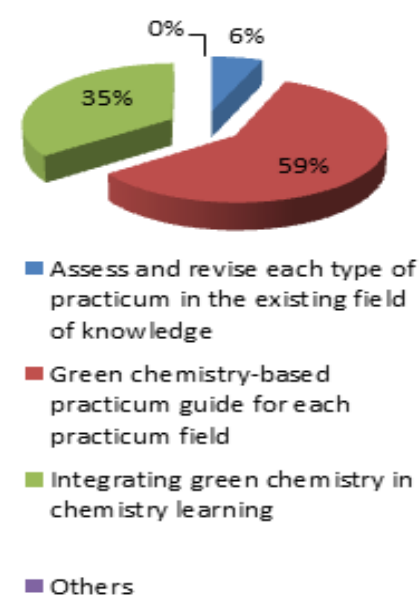

Figure 3. Results of The Fifth Question About Green Chemistry

These results indicate that the majority of students choose green chemistry-based practice guide for laboratory experiment. This result is also supported by $98 \%$ of students who claim to support the implementation of green chemistry-based chemistry experiment in Chemistry and Chemistry Education Study Program.

\subsection{Results of the Education Analysis for Sustainable Development}

At the end of the implementation phase, after applying a sustainable chemistry-based chemical kinetics module, students as respondents were given a questionnaire related to the educational paradigm for sustainable development. The results of the questionnaire indicate that as many as $76 \%$ of students understand the importance of instilling that humans are part of a social system that must synergize with other humans. In addition, education for sustainable development also instills awareness that humans are part of a natural system that must synergize with nature and all its contents. Thus each individual plays an active role in maintaining the sustainability of the planet and the sustainability of the universe as a whole.
From these results, it can be said that students know the educational paradigm for sustainable development. Students aware that humans are part of a social system that must synergize with other humans and part of the natural system that must synergize with nature and all its contents. So, hopefully every individual can play an active role in maintaining the sustainability of the planet earth and the overall sustainability of the universe. It is very good to be the foundation of a foothold on the way forward; students will become individuals who play an active role in maintaining sustainability.

In the second question, "Do you think there is a relationship between the application of green chemistry and the education paradigm for sustainable development?" 90\% answered yes and $10 \%$ said no. This result is a positive result in this study, since almost all students aware that there is a relationship between applying green chemistry principle and education paradigm for sustainable development. Therefore students are expected to be active in the future by protecting the environment through the application of green chemistry principles both in daily life and in the education process.

In the third question, the researchers found that $99 \%$ of college students stated that green chemistry-based experiments could be one way to maintain the overall sustainability of the universe. These results indicate that the module can be an inspiration for students to play an active role in maintaining the sustainability of the planet and the overall sustainability of the universe.

Then on the last question related to education for sustainable development is "Does your attitude become more concerned about the environment after following the chemistry 

Values

practice based on green chemistry?" 100\% results answered yes. These results indicate the achievement of one of the objectives of applying green chemistry besed experiment module that makes students care about the environment after understanding the paradigm of education for sustainable development.

\subsection{Cost Efficiency Analysis Results}

The use of the principle of green chemistry in the process of experiment, in addition to providing science related to green chemistry and build the educational paradigm for sustainable development this research also analyzes the cost issued. This experiment consists of six titles, conducted once a year for three classes, consist of two classes of chemistry education study program and one class of chemistry. In each class, there are 15 groups. The total cost used for kinetic's experiment after using the principle of green chemistry was reduced by $75 \%$. This proves that the use of kinetics experiments based on green chemistry modules besides being able to reduce waste can also reduce costs for chemicals used in kinetic's experiment every year.

\section{CONCLUSION}

This research produces Chemical Kinetic experiment guide based on Green Chemistry, which contains introduction, laboratory safety sheet, and evaluation sheet. Result of Feasibility percentage based on a feasibility test by material expert equal to $91.9 \%$, media expert test result equal to $94.7 \%$. The result of trial test by small group of students is $70.5 \%$, result of trial test by large group of students is $72 \%$ and the result of trial test by the teacher $90 \%$. The conclusion of experimental results conducted by researchers green chemistrybased kinetics module already has good criteria and is in accordance with the wishes and needs of students and makes students understand and apply the principles of green chemistry. In addition, it was also found that by using green chemistry based chemistry kinetic's module, there will be a cost saving for of $75 \%$ each year. 

Values

\section{REFERENCES}

Anastas, P. T., Kirchhoff, M. M., \& Williamson, T. C. (2001). Catalysis as a foundational pillar of green chemistry. Applied Catalysis A: General, 221(1-2), 3-13.

Anastas, P. T., \& Warner, J. C. (1998). Principles of green chemistry. Green chemistry: Theory and practice, 29-56.

Aubrecht, K. B., Padwa, L., Shen, X., \& Bazargan, G. (2015). Development and Implementation of A Series of Laboratory Field Trips for Advanced High School Students to Connect Chemistry to Sustainability. Journal of Chemical Education, 92(4), 631-637.

Beaulne, M. (2009). Why We Need Green Chemistry, healthylegacy.org/healthylegacy /files/whyneedgreenchemistry.pdf.

Burmeister, M., Rauch, F., \& Eilks, I. (2012). Education for Sustainable Development (ESD) and chemistry education. Chemistry Education Research and Practice, 13(2), 5968.

Fitrian, S. M. S., \& Fadiawati, N. (2014). Pengembangan Prosedur Praktikum Pengaruh Katalis Terhadap Laju Reaksi Berbasis Green Chemistry. Jurnal Pendidikan dan Pembelajaran Kimia, 3(3).

Gall, M. D., Gall, J. P., \& Borg, W. R. (2007). Educational Research: An Introduction, 8th Edition. UK: Pearson.

Jegstad, K. M., \& Sinnes, A. T. (2015). Chemistry Teaching for the Future: A model for secondary chemistry education for sustainable development. International Journal of Science Education, 3(4), 655-683.
Karpudewan, M., Roth, W. M., \& Ismail, Z. (2015). The effects of "Green Chemistry" on secondary school students' understanding and motivation. The Asia-Pacific Education Researcher, 24(1), 35-43.

Singh, M. M., Szafran, Z., \& Pike, R. M. (1999). Microscale chemistry and green chemistry: Complementary pedagogies. Journal of Chemical Education, 76(12), 1684.

Summers, M., Childs, A., \& Corney, G. (2005). Education for sustainable development in initial teacher training: Issues for interdisciplinary collaboration. Environmental Education Research, 11(5), 623-647.

Wahyuningsih, A. S. (2017). Pengembangan Modul Praktikum Kimia Dasar Berbasis Green Chemistry untuk Mahasiswa Calon Guru Ipa. Jurnal Pena Sains, 4(1), 43-51.

Wals, A. E. (2012). Shaping the Education of Tomorrow: 2012 Full-length Report on the UN Decade of Education for Sustainable Development. Unesco.

Wardana, M. D. K., \& Sultoni, S. (2017). Prosiding Seminar Nasional Pendidikan Desain Pembelajaran di Era Asean Economic Community (AEC) Untuk Pendidikan Indonesia Berkemajuan.

Wardencki, W., Curyło, J., \& Namiesśnik, J. (2005). Green Chemistry--Current and Future Issues. Polish Journal of Environmental Studies, 14(4). 